\title{
A SYSTEM FOR MOUNTING END CAPS ON ICE SPECIMENS
}

\author{
By D. M. COLE, L. D. Gould, and W. B. BurCH
}

(Cold Regions Research and Engineering Laboratory, Hanover, New Hampshire 03755, U.S.A.)

\begin{abstract}
This short note describes the equipment and procedures we have developed to mount end caps on ice-core specimens. The system typically achieves end-plane parallelism within $0.5 \mu \mathrm{m} / \mathrm{mm}$ of specimen diameter (i.e. a total indicator run-out of 0.002 in for a 4.0 in diameter specimen). The essential elements of the system are a holder and an alignment fixture. The holder firmly grips the ice core about its circumference by the compression of two series of O-rings. The alignment fixture clamps the holder to align the ice core precisely with the end caps. To bond the ice to the end cap we form a layer of $0{ }^{\circ} \mathrm{C}$ water on the end cap; the water freezes immediately upon contact with the ice and forms a strong intimate bond. To date, we have used this system to install phenolic end caps on $101.6 \mathrm{~mm}$ diameter cores and aluminum end caps on $76.2 \mathrm{~mm}$ diameter cores of saline ice. We obtained a somewhat better tolerance with the aluminum caps ( $0.33 \mu \mathrm{m} / \mathrm{mm}$ of end-cap diameter), due primarily to the geometric stability of that material under the prevailing conditions. These specimens have been successfully tested in uniaxial and triaxial compression, and we expect that with appropriate end caps the system will be suitable for preparing tension specimens as well.
\end{abstract}

RÉSUMÉ. Un systéme de montage de flasques en bout d'échantillons de glace. Cette courte note décrit l'équipement et le procédé que nous avons développé pour monter des flasques en bout d'échantillons de glace. Le système permet d'assurer le parallélisme des plans de montage avec $0,5 \mu \mathrm{m}$ par $\mathrm{mm}$ de diamètre de l'échantillon (c'est-à-dire une indication d'écartement de 0,002 pour 4 dans le diamètre de l'échantillon). Les éléments essentiels du système sont un support et un appareillage d'alignement. Le support enserre fermement la carotte de glace sur sa circonférence par compression de deux séries de O-ring. L'appareillage d'alignement serre le support pour aligner précisément la carotte avec les flasques. Pour fixer la glace aux flasques on produit une couche d'eau à $0^{\circ} \mathrm{C}$ sur la base du flasque; l'eau gèle immédiatement au contact de la glace et constitue

\section{INTRODUCTION}

This note describes the equipment and procedures for an end-capping system that overcomes the problems associated with precisely bonding end caps to an irregular ice-core specimen.

The quality of results from mechanical tests on ice depends in large part on the precision of the specimen geometry. Poor control of the dimensional tolerances can influence both the reproducibility of test results and the character of deformation. This problem is minimized when an individual specimen is grown in the laboratory where geometry and end-cap tolerances can be established by a properly constructed mold (Cole, 1979). However, the problem becomes much more difficult when end caps are to be bonded to core samples. Typically, the diameter of a core sample varies to a certain extent and this, coupled with the problems associated with rigidly clamping a brittle material such as ice, makes it difficult to machine a segment of core into an acceptable test specimen. un collage intime et résistant. Par example nous avons utilisé ce système pour placer des flasques phénoliques sur des carottes de $101,6 \mathrm{~mm}$ de diamètre et des flasques d'aluminium sur des carottes de glace salée de $76,2 \mathrm{~mm}$ de diamètre. Une meilleure tolérance a été obtenue avec les flasques d'aluminium $(0,33 \mu \mathrm{m} / \mathrm{mm}$ pour le diamètre de la flasque), ce qui est da principalement à la stabilité de ce matériau dans ces conditions d'expériences. Ces échantillons ont été testés avec succès dans une compression uniaxiale et triaxiale, et nous prévoyons qu'avec des flasques approprié le système sera aussi adéquate pour tester des échantillons en traction.

ZUSAMMENFASSUNG. Ein System zur Montage von Endkappen an Eisproben. Diese kurze Notiz beschreibt die Gerăte und Verfahren, die wir zur Montage von Endkappen an Eisproben entwickelt haben. Das System ist gekennzeichnet durch eine erreichbare Parallelităt von $0,5 \mu \mathrm{m}$ pro $\mathrm{mm}$ Probedurchmesser (d.h. eine maximale Abweichnug von 0,002 in bei einem Durchmesser von 4 in). Die wesentlichen Elemente des Systems sind eine Halterung und eine Ausrichtlehre. Die Halterung fasst den Eiskern durch Kompression zweier Serien von O-Ringen fest an seinem Umfang. Die Ausrichtlehre führt die Halterung präzis in die Verbindungsgerade der Endkappen. Zur Bindung des Eises an die Endkappen erzeugen wir an diesen eine Wasserschicht von $0^{\circ} \mathrm{C}$; das Wasser gefriert beim Kontakt mit dem Eis sofort und bildet eine starke, enge Bindung. Bisher haben wir dieses System zur Anbringung von Phenol-Endkappen an Kerne von 101,6 mm Durchmesser und Aluminium-Endkappen an salzhaltige Eiskerne von $76,2 \mathrm{~mm}$ Durchmesser benutzt. Wir erzielten eine etwas bessere Toleranz mit den Aluminium-Kappen $(0,33 \mu \mathrm{m}$ pro $\mathrm{mm}$ Durchmesser der Endkappen), vor allem infolge der geometrischen Stabilität dieses Materials unter den gegebenen Bedingungen. Diese Proben wurden erfolgreich unter ein- und zweiachsiger Kompression getestet; wir erwarten, dass das System sich mit entsprechenden Endkappen auch zur Herstellung von Dehnungsproben als geeignet erweist.

We have developed a system consisting of a holder, or sabot, that firmly grips the ice core and an alignment fixture that holds the sabot and the end caps in position while the end caps freeze on to the specimen.

\section{GENERAL DESCRIPTION}

The sabot (Fig. 1) holds the ice specimen by means of a series of O-rings at each end that are compressed about its circumference. Figure 2 shows a cross-sectional view of the O-ring and spacer-ring configuration. The symmetry of the O-ring configuration by nature aligns the center of the specimen with the long axis of the sabot. The compressed O-rings rigidly hold the specimen in the sabot, which may in turn be tightly clamped into a lathe or milling machine for careful trimming of the specimen ends. Once tightly gripped in the sabot, the specimen is not removed until all operations are complete.

After the specimen ends are trimmed, the sabot is clamped to the carriage on the alignment fixture. The 


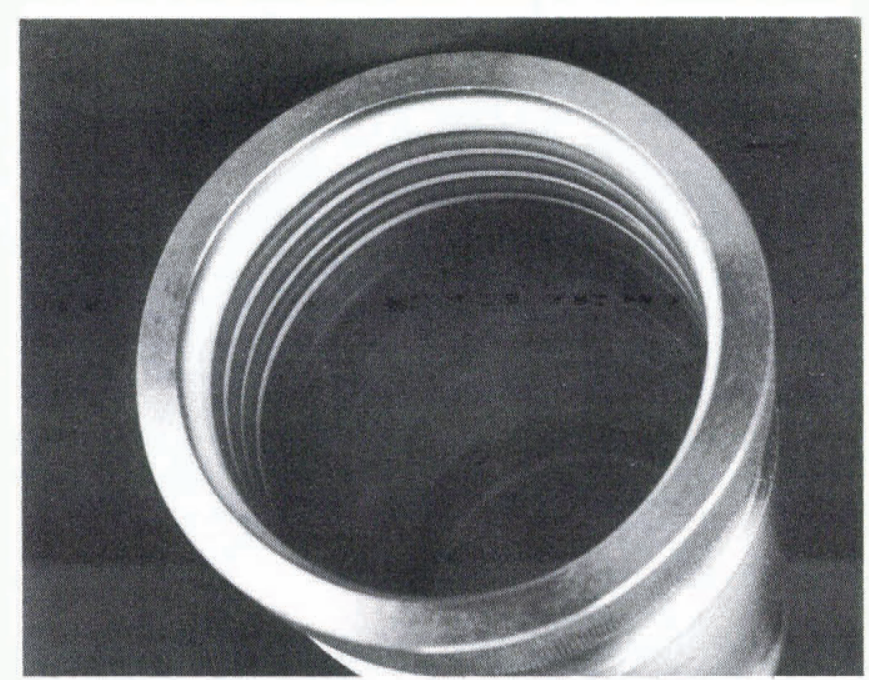

Fig. 1. Sabot.

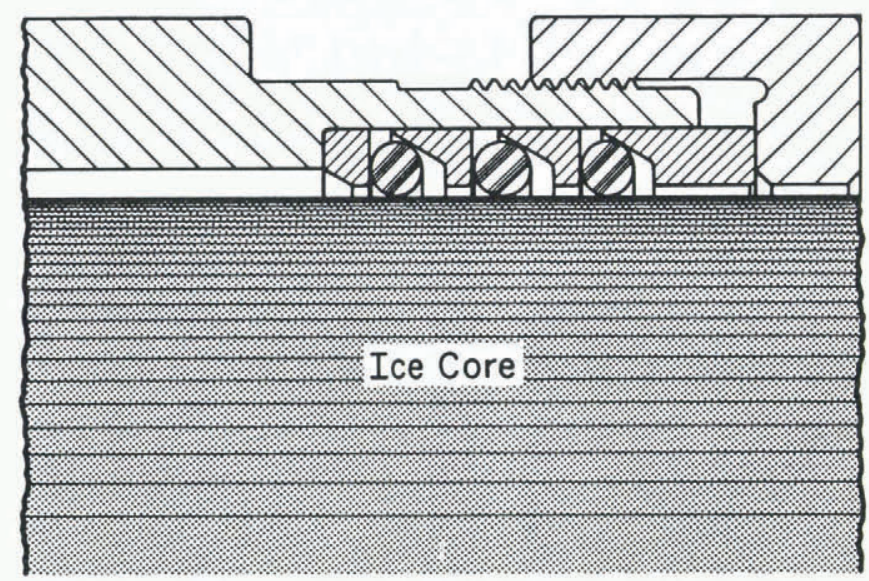

Fig. 2 Detail of O-ring configuration.

carriage has been carefully machined to align axially the sabot, and thus the specimen, with the locater pins on the alignment fixture. The locater pins in turn hold the end caps parallel and axially aligned with each other. The carriage slides on two vertical shafts to bring the ice into contact with the end caps, allowing the end caps to be frozen to the specimen one at a time. A thin layer of $0{ }^{\circ} \mathrm{C}$ water, placed on the end cap just prior to contact with the ice, freezes immediately and forms an intimate bond.

It is primarily the precision with which the locater pins are mounted that establishes the precision of the mounting system itself. We have observed that the phenolic end-cap material distorts noticeably as a result of water absorption and freezing, making it difficult to isolate the errors associated with the method of end-cap mounting from the errors generated by end-cap distortion. The values reported for end-cap parallelism thus contain errors from both these sources. A finished specimen, $101.6 \mathrm{~mm}$ in diameter and $254 \mathrm{~mm}$ long, has end caps that are concentric to within $0.13 \mathrm{~mm}$ and parallel to within $0.5 \mu \mathrm{m} / \mathrm{mm}$ of end-cap diameter (i.e. total indicator run-out of $0.05 \mathrm{~mm}$ ).

\section{DESIGN DETAILS}

The sabot design results in the radial compression of the O-rings as the clamping caps are threaded inward. Figure $3 \mathrm{a}$ shows the relative movement of an O-ring and spacer ring as the clamping cap is tightened. We used precision silicon-rubber O-rings of $6.35 \mathrm{~mm}$ cross-sectional thickness that have successfully clamped core segments that were $0.51 \mathrm{~mm}$ under the nominal design diameter of $101.6 \mathrm{~mm}$. The O-ring material retains its elasticity at low
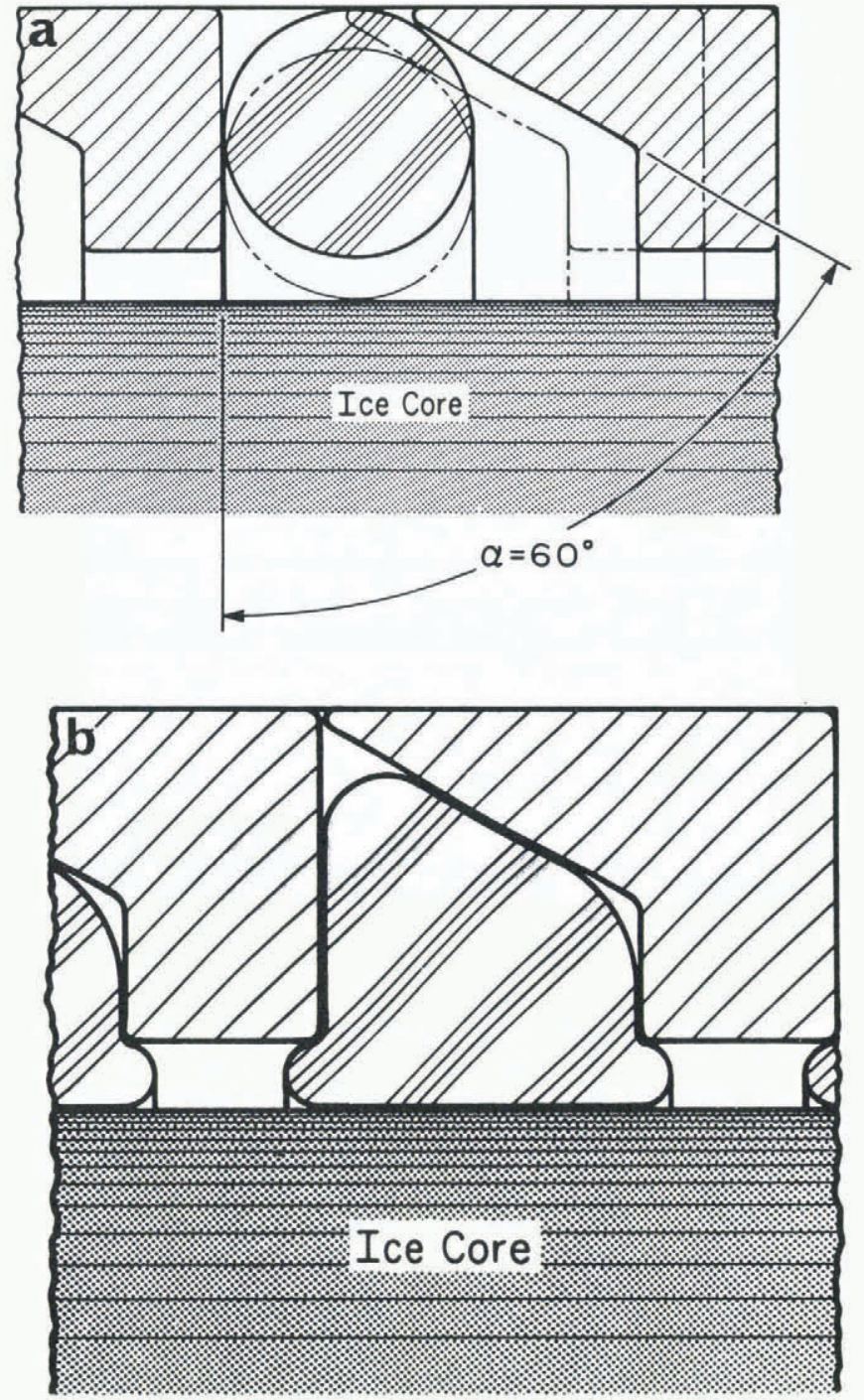

Fig. 3. a. Motion of O-ring as spacer rings are compressed.

b. Final position of $O$-ring configuration showing compression of $\mathrm{O}$-ring about the ice core.

temperatures and thus undergoes the necessary distortion without requiring an excessive clamping force.

The spacer rings are made of acetal resin (Delrin) and have a $30^{\circ}$ taper. As the clamping caps compress the $\mathrm{O}$-ring and spacer-ring configuration, the $\mathrm{O}$-rings are constrained from buckling while they are forced radially inward. Eventually, the O-rings make contact with the ice core and assume a shape similar to that shown in Figure $3 \mathrm{~b}$. The clamping caps are screwed in until the radial clamping force is sufficient to hold the specimen during subsequent operations. The actual end-capping operation is done on the alignment fixture (Fig. 4). This device provides a means to hold precisely both the end cap and the sabot while the two are brought into contact. The sabot is clamped on to the carriage of the alignment fixture and the end caps are placed on locater pins on the end plates of the fixture. The locater pins precisely align the end caps with the long axis of the sabot.

The carriage rides on two ground-steel shafts and has two linear ball-bushings per shaft. The carriage bushings are pre-loaded to eliminate radial play in the system. It is also equipped with a brake so it can be held at any location along its travel.

\section{END-CAPPING PROCEDURE}

The clamping rings are hand tightened sufficiently to grip firmly the specimen but not so tight as to damage it. The specimen is then cut roughly to length on a band saw. 


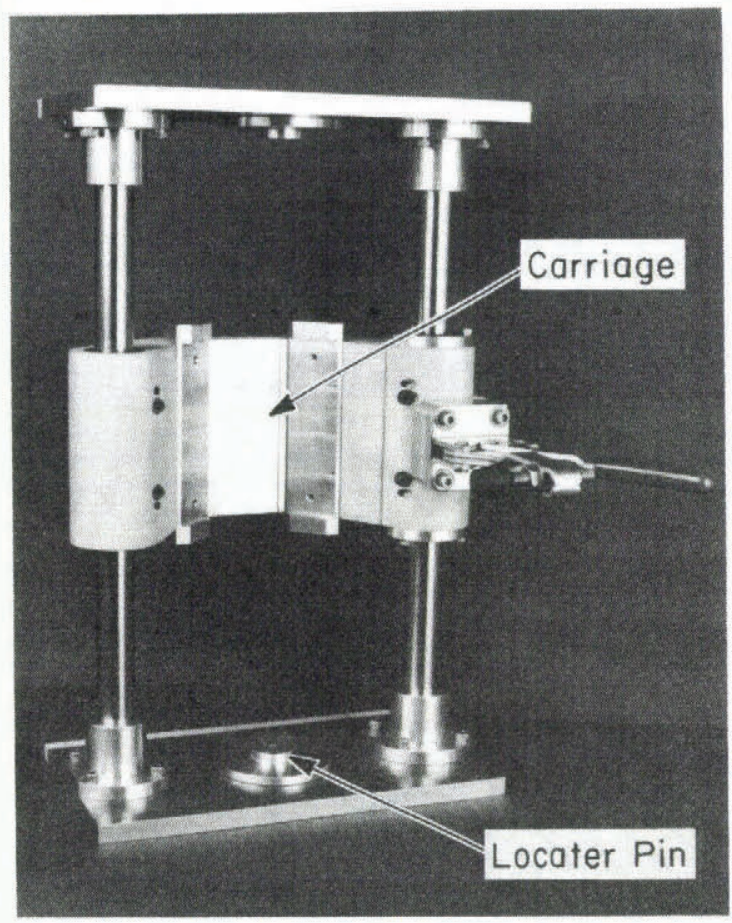

Fig. 4. Alignment fixture.

Approximately $20 \mathrm{~mm}$ of ice protrudes from each end of the sabot after this. The sabot is then clamped on to a V-block mounted on the table of a milling machine (Fig. 5) and the ice is machined to length. The alignment fixture is not sensitive to small errors in the parallelism of the end faces of the machined ice specimen and it has compensated for errors of $1.3 \mu \mathrm{m} / \mathrm{mm}$ of specimen diameter. It is desirable, however, to machine the ice accurately in order to keep the bonding layer as thin and uniform as possible.

After the milling operation, the sabot is placed in the carriage of the alignment fixture. At this point, the carriage holds the lower end of the specimen above an end cap that has been placed on the bottom locater pin (Fig. 6). We then form a layer of $0^{\circ} \mathrm{C}$ distilled water on the end cap and carefully lower the carriage until the ice makes contact with the end cap. Excess water flows down the sides of the end cap and the remaining water quickly freezes, forming a strong intimate bond.

We use a fabric-based phenolic material that is water absorbent for the end caps which develops a particularly strong bond with ice (Cole, 1979). The bonding faces of the caps are machined with concentric grooves (Fig. 7) which expose additional fabric and increase the surface area. The caps are soaked in distilled water at $0^{\circ} \mathrm{C}$ prior to placement

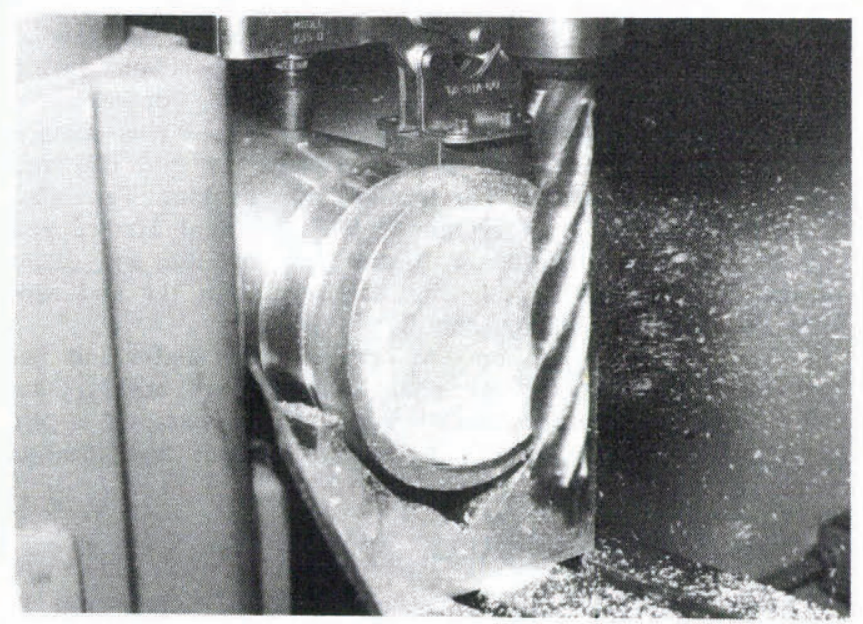

Fig. 5. The sabot is clamped in a V-block on the milling-machine table. Specimen ends are then trimmed.

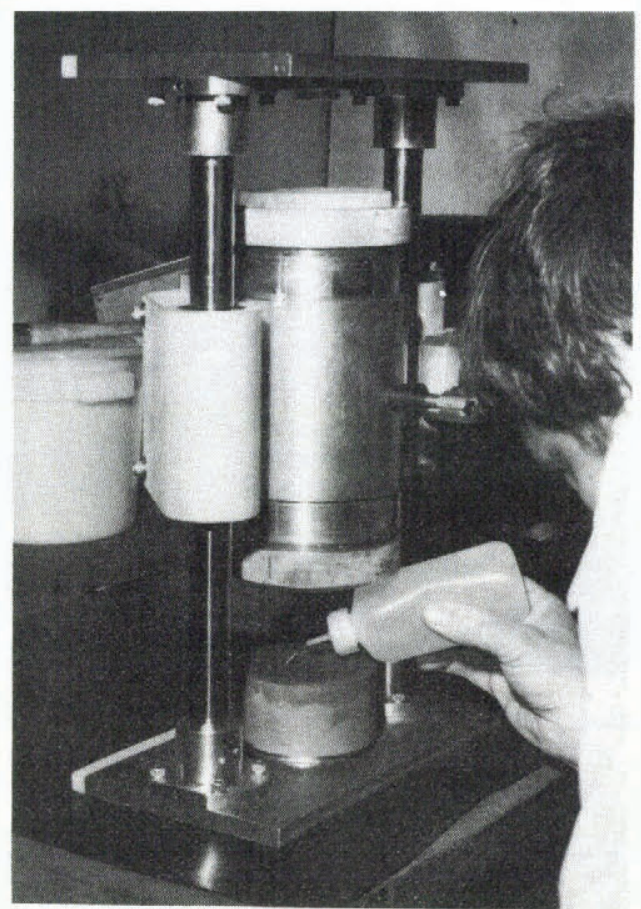

Fig. 6. Sabot and end cap placed in the alignment fixture. A layer of $0^{\circ} \mathrm{C}$ distilled water is formed on the end cap prior to lowering the specimen into contact.

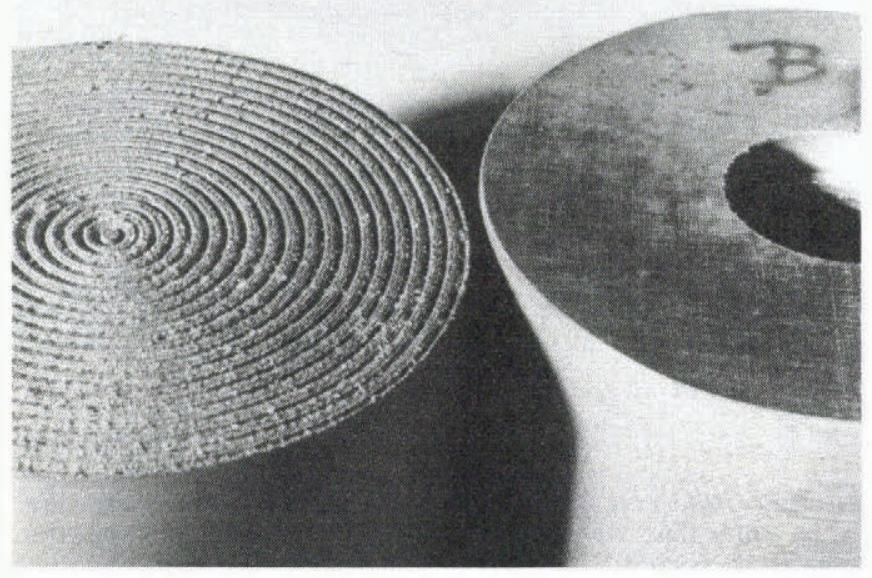

Fig. 7. Fabric-based phenolic end caps showing grooves for improved bonding.

on the alignment fixture. The basic end-cap geometry and the soaking procedure are after Mellor and others (1984).

After the first cap is in place, the fixture is rotated $180^{\circ}$ and the second end cap is mounted in exactly the same manner. The specimen is then removed from the sabot, measured, carefully wrapped and stored until testing. Figure 8 shows a typical end-capped specimen.

\section{DISCUSSION}

The entire end-capping procedure requires approximately $30-40 \mathrm{~min}$ per sample. The system requires only basic machine-operation skills and a general appreciation of the need for precision. The system may be used for specimens with a diameter less than the $101.6 \mathrm{~mm}$ design diameter, although this requires fabrication of appropriately sized sabot, V-block, and spacers for the carriage. We are currently equipped for capping $76.2 \mathrm{~mm}$ diameter specimens as well as the $101.6 \mathrm{~mm}$ diameter ice specimens. Using aluminum end caps for the $76.2 \mathrm{~mm}$ diameter specimens, we have achieved end parallelism to within $0.33 \mu \mathrm{m} / \mathrm{mm}$ of end-cap diameter. We attribute this improvement over the $101.6 \mathrm{~mm}$ diameter specimen primarily to the geometric stability of the aluminum end caps. 


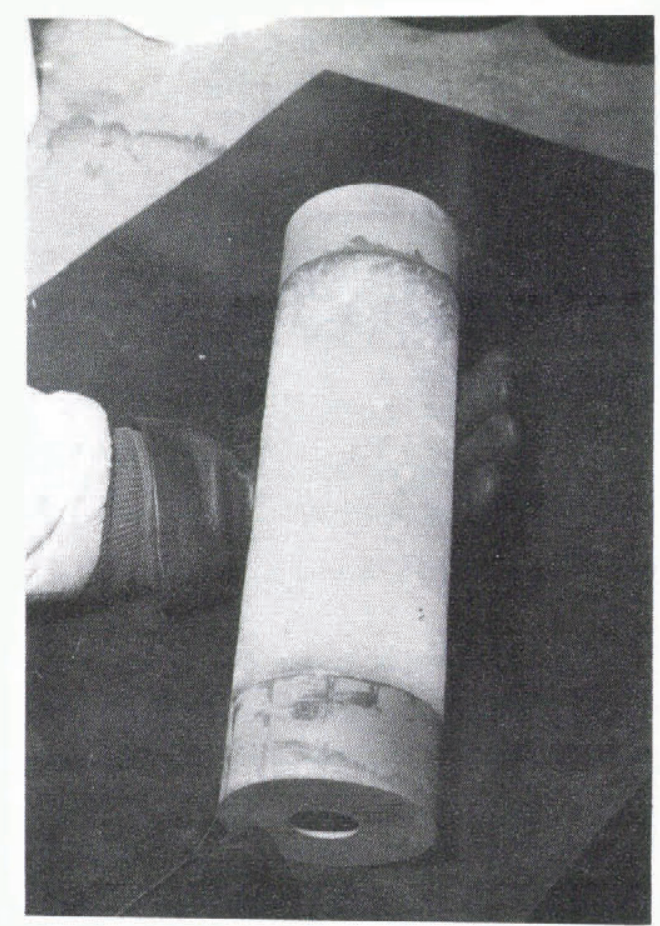

Fig. 8. Typical saline-ice specimen with end caps installed.

A precise, reliable technique for mounting end caps is essential to any ice-specimen preparation procedure. It is especially important in tests where ice is compressed between rigid loading platens (i.e. no ball seat is used), tested under high rates of loading, and tested in tension. Significantly, non-parallel end caps can increase the scatter in the results under all of these test conditions by causing stress concentrations and bending moments in the material.

Properly mounted end caps can greatly reduce data scatter from those two sources. Carefully prepared and wellaligned tension specimens produced in the laboratory by Lee (unpublished) had an impressively small 4\% scatter in fracture stress. Lee's specimen geometry was controlled by the mold construction which resulted in maximum errors $0.79 \mu \mathrm{m} / \mathrm{mm}$ of end-cap diameter. This error in parallelism for molded specimens is comparable to that observed with our apparatus for cored specimens. Other techniques (Mellor and others, 1984) for end-capping field cores that do not employ the sabot concept or a rigid alignment fixture typically achieve parallelism within $2.4 \mu \mathrm{m} / \mathrm{mm}$ of end-cap diameter.

We plan to fabricate a system for mounting the sabot on a lathe, rather than a milling machine, for machining the ends of the ice specimen. Such a system would provide greater precision with less effort and thus improve the efficiency of the end-capping method.

\section{ACKNOWLEDGEMENT}

The authors express their appicciation for the creative assistance of R. Roberts, CRREL, in the development of the procedure outlined in this paper.

\section{REFERENCES}

Cole, D.M. 1979. Preparation of polycrystalline ice specimens for laboratory experiments. Cold Regions Science and Technology, Vol. 1, No. 2, p. 153-59.

Lee, R.W. Unpublished. The effect of grain size on the tensile strength of ice at two strain rates. [M.Sc. thesis, Thayer School of Engineering, Dartmouth College, Hanover, NH, 1985.]

Mellor, M., and others. 1984. Mechanical properties of multi-year sea ice; testing techniques, by $M$. Mellor, G.F.N. Cox, and H.W. Bosworth. CRREL Report 84-8. 